\title{
Effects of Internal Factors on Nonperforming Loans of Vietnam's Commercial Banks
}

\author{
BUI DUY TUNG \\ University of Economics HCMC - tungbd@ueh.edu.vn \\ DANG THI BACH VAN \\ University of Economics HCMC - bachvan@ueh.edu.vn
}

\section{ARTICLE INFO ABSTRACT}

Article history:

Received:

Mar. 102015

Received in revised form:

Oct. 082015

Accepted:

June 202016
This paper employs dynamic panel data to assess the effects of bankspecific factors on nonperforming loans (NPLs) of Vietnam's commercial banks between 2004 and 2014. Using two-step GMM estimator besides other macro variables, we find that the nonperforming loans are affected by various factors, including management quality and moral hazard along with their negative impacts. The results are consistent with previous theoretical suggestions. Particularly, ownership concentration reveals opposite results to the proposed theories, and no evidence can be found on the hypothesis that diversification of banking activities may reduce the level of nonperforming loans.

Keywords:

Nonperforming loans, dynamic panel data, GMM, Vietnam, dynamic panel data methods. 


\section{Introduction}

Credit institutions, in their operations, inevitably incur nonperforming loans (NPLs) now that lending activities always entail risk. Since the 2007-2008 financial crisis, the issue of NPLs has attracted rapt attention of researchers and policy makers (Guy, 2011), whereas according to Reinhart and Rogoff (2010), Nkusu (2011), and Louzis et al. (2012), they are regarded as being indicative of future's financial crisis if not sufficiently tracked and promptly solved. In recent years the quality of assets, notably nonperforming assets, is a topmost concern in determining banking efficiency (Karim et al., 2010).

In Vietnam the commercial banking system plays a significant role in free circulation of capital flows, facilitating socioeconomic development. Yet, for the 2004-2014 period, NPLs became a burden born by the system, which in turn, particularly since 2008, has been suffering a rise in the loans (over 3\% mostly during 2011-2014 and over 3.57\% for 2012-2013). In April 2012 SBV promulgated Decision No.780/QD-NHNN, which allows credit institutions to make amendments to repayment terms and extend maturity dates for enterprises with debt repayment problems.

The decision aimed to support enterprises and remove the barriers of NPLs in addition to being a means to assist credit institutions in reducing their actual nonperforming rates. Thus, the rates of NPLs might even be much higher. High nonperforming rates did affect the operation of the banking system as well as the entire economy: (i) commercial banks could not proceed their lending once NPLs accounted for a large proportion in the balance sheet, indirectly causing difficulties in enterprises' access to capital sources; (ii) prolonged NPLs gave rise to tangible and intangible costs of commercial banks; (iii) the central bank's monetary policy became less effective due to low performance of the commercial banking system; and (iv) high NPLs led to a decline in profitability and credentiality of the banking system. On the other hand, by using dynamic panel data for analysis, it is realized that the average NPL ratio of commercial banks with state-owned capital is higher than the others in the system. 


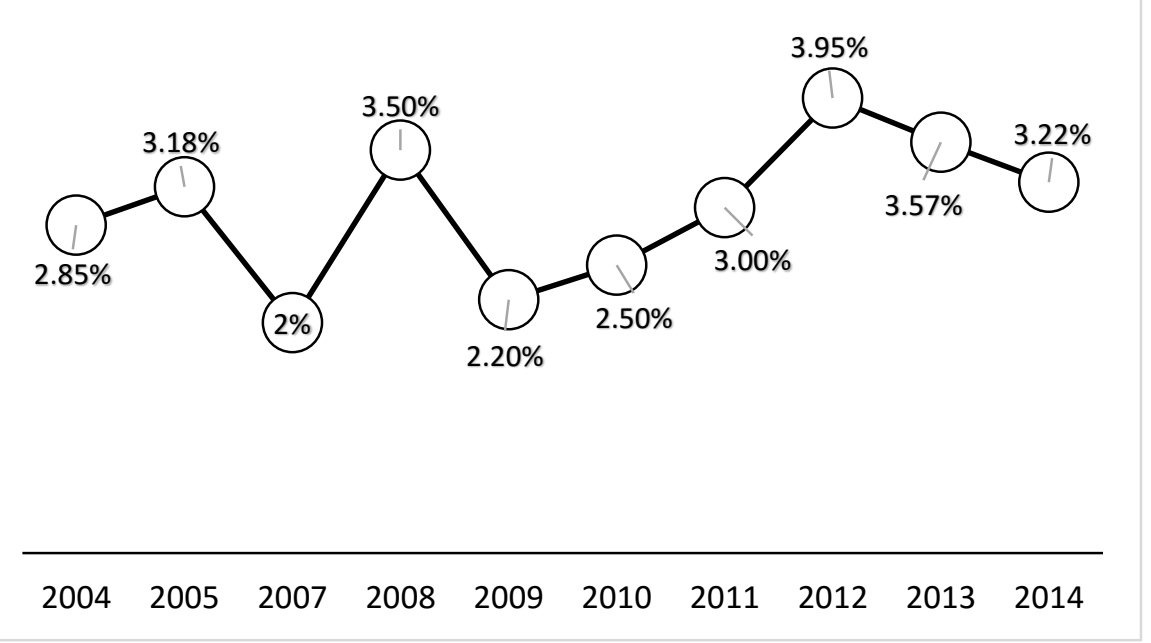

Figure 1. NPLs of the banking industry between 2004 and 2014

Source: SBV's annual reports and website

The year 2015 has been determined by the central bank as the pivotal year to implement the scheme on handling NPLs and the ending year of the one on restructuring the system of credit institutions. Particularly, it has been affirmed that NPLs reduce to below 3\%, that poor performance of credit institutions are decisively tackled, and that mergers and acquisitions, financial strengthening and restructuring of business operations and innovation of administrative systems are to be implemented. Empirical researches showed that apart from macroeconomic factors, NPLs suffered by banking institutions are profoundly impacted by intrinsic activities themselves (Salas \& Saurina, 2002; Louzis et al., 2012; Abid et al., 2014). Berger and DeYoung (1997) also suggested a causal relationship between internal factors like management quality and moral hazard and NPLs.

Following Berger \& DeYoung's (1997) study, we analyze the impact of internal factors on NPLs of Vietnam's commercial banks for the 2004-2014 period, and identify which and how these factors actually exert the effect on NPLs. 


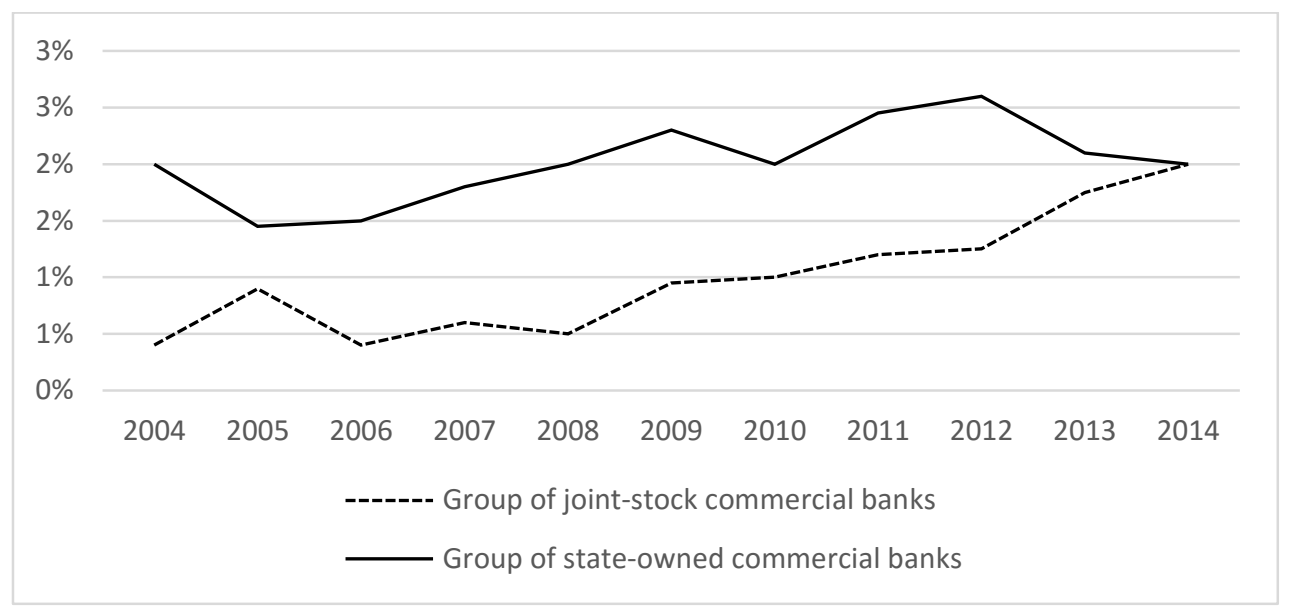

Figure 2. Average NPLs rates in terms of equity capital

\section{Theoretical bases and methodology}

To achieve the aims of this study, we attempt to determine which bank's internal factors have significant effects on NPLs after controlling for macro factors within the scope of the whole system.

\subsection{Literature on internal factors and their effects on NPLs of commercial banking} institutions

NPLs are universally known to relate to three factors: (i) payments of principal and/or interest past due by 90 days or more (IMF's Financial Soundness Indicators Guide); diminution in repayment capability of the borrower; and (iii) loans categorized into being sub-standard, doubtful, and loss (as recommended by IFF) (Barisitz, 2011). However, due to the inconsistence in analytical framework for loan classification across countries, Barisitz (2013) suggested that a loan is nonperforming if there exists one of the two criteria: (i) 90 days or more overdue (quantitative aspect); and (ii) borrower's reduced capability to pay for loans (qualitative aspect). Louzis (2011) also utilized the quantitative factor to estimate the NPL ratio.

In Vietnam, Nguyen (2013) claimed that NPLs are those which are substandard and considered doubtful in terms of both borrower's repayment capability and creditor's capital recovery, occurring in the cases of insolvency declaration and gradual property sales. Moreover, it was argued by Dinh (2012) that the definition of NPLs of Vietnamese commercial banks that debt repayment past due by 91 days and more, quantitatively 
speaking, is quite congruent with international standards. Other studies by Nguyen (2012) and Nguyen (2013) also agreed upon the association between NPLs and 90 days criterion and borrower's diminishing repayment capability. Accordingly, NPLs are referred to from both quantitative and qualitative perspectives; nevertheless, since it is hard to identify qualitative elements (Nguyen, 2013; Dinh, 2012), NPLs in this study is perceived to be more than 90 days overdue loans.

NPL ratio $=($ NPLs/total loans $) * 100 \%$

The higher the ratio, the poorer the asset quality and the greater the credit risk. Empirical research indicated that NPLs are governed by distinct banking activities. Managerial quality is manifested by efforts to improve efficiency, control over operation costs or returns on equity, management practices of risk and moral hazard, the level of control by the owner, and so forth.

\section{Bank management quality}

In examining the causal relationships among loan quality, cost efficiency, and bank capital, Berger and DeYoung (1997) detected poor management as a significant contribution to a rise in NPLs. Bad management practices are associated with poor skills in credit scoring, collateral appraisal, and monitoring borrower's activities, and thus are likely to subsequently lead to increased NPLs. Louzis et al. (2012) and Abid et al. (2014) employed the ratio of expenses to income to estimate banks' management efficiency.

Their empirical findings showed that the expense-to-income ratio relates positively and significantly to NPLs. It was also hypothesized from this perspective that the management quality is measured not only by cost efficiency but also bank performance. Both Louzis et al. (2012) and Abid et al. (2014) maintained that bank performance in the previous year has a negative correlation with NPLs in the future. In this regard, ROE is used to measure performance in the surveyed periods. Thus, this study proposes the first hypothesis on bank management quality, represented by ROE and the ratio of expenses to total income, which are negatively and positively related to NPLs, respectively.

\section{H1: Management quality negatively relates to NPLs.}

\section{Moral hazard}

For banks with low liquidity, managers tend to use funds to invest in risky credit activities, resulting in moral hazard during operations as attempts to accelerate credit growth in anticipation of more profits in order to improve bank liquidity are often 
coupled with higher risk from different loans. Berger and DeYoung (1997) argued that a low proportion of equity capital commonly leads to an increase in NPLs then.

Salas and Saurina (2002), Louzis et al. (2012), and Abid et al. (2014) adopted bank size and liquidity (equity-to-asset ratio) as proxies for moral hazard, whereas Gueddoudj (2013) used liquidity as its sole proxy. Since earlier findings suggested that these two factors have negative impacts on banks' NPLs, we inspect the next hypothesis on moral hazard as is proxied by liquidity.

\section{H2: Moral hazard negatively relates to NPLs.}

\section{Diversification in banking activities}

Besides the mentioned factors, some studies have verified the profound effect of diversification on reducing NPLs in banking operations. Salas and Saurina (2002), Hu et al. (2004), and Rajan and Dhal (2003) assented to the negative impact of diversification on NPLs, whereby bank size was used as a proxy for banking diversification. Larger bank size is linked with more opportunities to implement diversification, thereby leading to decline in bank risk. Apart from bank size, another variable depicting the degree of diversification is non-interest income.

Louzis et al. (2012) adopted both bank size and non-interest income to proxy for diversification, finding that the two factors negatively and significantly influence NPLs. Accordingly, the third hypothesis can be formulated with non-interest income as a proxy variable.

H3: Diversification in banking activities negatively relates to NPLs.

\section{Ownership control}

According to the theory proposed by Berle and Means (1932), ownership concentration would enhance performance of enterprises, especially financial ones (Shehzad et al., 2010). The more concentrated the bank ownership, the greater caution is exercised about risk via stricter control over loans. The level of ownership is negatively correlated with NPLs (Iannotta et al., 2007; Shehzad et al., 2010). These studies documented that ownership control contributes to mitigating the effects of moral hazard.

We conduct a test on the fourth hypothesis to estimate the effect of ownership control on NPLs of Vietnam's commercial banks by using the variable level of shareholding, which has been also employed in earlier investigations as a proxy for ownership control. 
By this means, Laeven and Levine (2008) documented two levels of over $10 \%$ and over $20 \%$, whereas Shehzad et al. (2010) uncovered an even higher degree. Furthermore, the system of Vietnamese commercial banks is mainly composed of state-owned and other joint-stock banks with the level of ownership within the ranges of over $10 \%$ and over $50 \%$. Thus, we choose to adopt the levels of ownership of an individual and/or organization of over $10 \%$, over $25 \%$, and over $50 \%$ of bank's charter capital.

H4: The level of ownership control negatively relates to NPLs.

NPLs of commercial banks are affected not only by internal factors in banking activities but also by the economy itself and other macro factors. Carey (2002) observed that a nation's economy is one among many macro elements with the most powerful impact that causes less diversification in loan portfolios. Additionally, NPLs are endogenous, affected by the growth factor GDP, and heavily depend on inflation and lending rates. These variables, together, provide an advantageous framework for screening the problem of NPLs (Guyb, 2011). For this reason we consider macro factors in their function as control variables when investigating the impact of bank-specific factors on NPLs, which enforces our findings' reliability.

\subsection{Methodology}

Many studies on NPLs should take into account the interaction between their different values over time. Thus, in modelling NPLs autoregressive model is often a viable option. In the event of panel data as the research sample, it is the dynamic panel model that is suitable to provide unbiased and robust estimations (Salas \& Saurina, 2002; Merkl \& Stolz, 2009; Louzis et al., 2012; Gueddoudj, 2013; Abid et al., 2014).

$$
\begin{aligned}
& y_{i t}=\alpha y_{i, t-1}+\beta(L) X_{i t}+\eta_{i}+\varepsilon_{i t} \\
& |\alpha|<1 ; \mathrm{i}=1,2,3, \ldots, \mathrm{N} ; \mathrm{t}=1,2,3, \ldots, \mathrm{T}
\end{aligned}
$$

where $i$ and $t$ denote the ordinal number of observations in terms of commercial banks and period of time, $y_{i t}$ denotes NPLs of bank $i$ in period $t, X_{i t}$ is $(\mathrm{kx} 1)$ vector of explanatory variables apart from $y_{i, t-1}, \beta(L)$ is $(1 \mathrm{xk})$ vector of regression coefficient in terms of lags of explanatory variables $X_{i t}, \eta_{i}$ denotes fixed effects, a proxy for unobserved differences among commercial banks, and $\varepsilon_{i t}$ denotes error terms. 
The regression coefficients of Eq. 1 are estimated using GMM estimator as proposed by Arellano and Bond (1991) and advanced by Arellano and Bover (1995) and Blundell and Bond (1998). By this approach Eq.1 can be converted to a differenced equation as follows:

$$
\Delta y_{i t}=\alpha \Delta y_{i, t-1}+\beta(L) \Delta X_{i t}+\Delta \varepsilon_{i t}
$$

where $\Delta$ is a first difference operator.

The differentiation allows for the correlation between $\Delta y_{i, t-1}$ and $\Delta \varepsilon_{i t}$ and causes unbiased estimations of Eq. 2. To overcome this problem of endogeneity, Arellano and Bond (1991) suggested using different lag lengths from $y_{i, t-2}$ as instrumental variables for $\Delta y_{i, t-1}$ since $y_{i, t-2}$ is correlated with $\Delta y_{i, t-1}$, but not with $\Delta \varepsilon_{i t}$, in case there is no serial correlation as reflected by $\varepsilon_{i t}$. We thus have:

$$
E\left\lfloor y_{i, t-s} \Delta \varepsilon_{i t}\right\rfloor=0 \text { with } \mathrm{t}=3, \ldots, \mathrm{T} \text { and } \mathrm{s} \geq 2 .
$$

Moreover, the assumption of total exogeneity of explanatory variables is no longer true in the case of reverse causality ( $E\left[X_{i s} \varepsilon_{i t}\right] \neq 0$ with $\mathrm{t}<\mathrm{s}$ ). Therefore, concerning explanatory variables being weakly endogenous or predetermined, only their lags are suitable to be used as instrument ones.

$$
E\left[X_{i, t-s} \Delta \varepsilon_{i t}\right\rfloor=0 \text { with } \mathrm{t}=3, \ldots, \mathrm{T} \text { and } \mathrm{s} \geq 2 .
$$

From the above assumption, Eq. 2 can be calculated using one-step GMM estimator. In the circumstances of independent error terms and homogeneous variances, the onestep GMM technique would offer robust estimations. On the other hand, if serial correlation or heteroskedasticity occurs, two-step GMM approach would provide better results. Nevertheless, the two-step estimator establishes the variancecovariance matrix on the ground of measuring residual terms, thus causing biased results of the t-test (Arellano \& Bond, 1991). For this reason we apply the adjusted variancecovariance matrix technique and differenced GMM in accordance with Windmeijer (2005). 
We conduct further tests on instrument variables with Hansen $\mathbf{J}$ test as estimations complying with Windmeijer's (2005) reveals no robustness in Sargan test results (Roodman, 2006). Furthermore, we consider serial correlation of $\varepsilon_{i t}$ by testing the null hypothesis that $\Delta \varepsilon_{i t}$ does not have second-order serial correlation; the fact that this hypothesis is rejected implies that $\varepsilon_{i t}$ has serial correlation and also that GMM estimators are no longer robust.

\subsection{Research model and data}

We design the research model examining internal factors and their impact on NPLs in addition to using macro factors as control variables.

$$
N X_{i t}=\alpha N X_{i, t-1}+\sum_{j=0}^{l} \beta_{1 j} X_{i, t-l}+\sum_{k=0}^{3} \beta_{2 k} Z_{t-1}+\eta_{i}+\varepsilon_{i t}
$$

where $N X_{i t}$ is the ratio of NPLs to total loans of bank $i$ in period $t$, and $Z_{t-1}$ is a set of macro control variables. These macro variables are employed in their lagged forms to control for behavior of economic agents over time; these subjects often make decisions and payments for their loans when obtaining sufficient information on the macro economy (Louzis et al., 2012; Gueddoudj, 2013; Abid et al., 2014).

$X_{i, t-l}$ is a vector of explanatory variables denoting internal factors of each commercial bank. As usual these are added to the model with lag- 1 on the assumption that they do not produce effects on NPLs at the same time due to the distinctness of accounting statistics; thus, it is required that there be a suitable lag length for a change in decisions made by bank management (Berger \& DeYoung, 1997; Louzis et al., 2012; Gueddoudj, 2013; Abid et al., 2014).

Moreover, the number of cross section units in the data sample is believed to limit that of the instrument variables and exogenous variables added to Eq. 3. Thus, internal variables each are introduced one by one to test relevant hypotheses, and the number of lags employed as instrument variables in the model will be controlled (Louzis et al., 2012; Abid et al., 2014). Judson and Owen (1999) explained that restricting the lags of instrument variables does not reduce the effectiveness of the GMM technique. Macro variables and some internal variables without lags are considered exogenous, whereas the remaining internal variables that are correlated with the error terms in the past and 
present but not with those in the future are regarded as weakly exogenous (Salas \& Saurina, 2002; Louzis et al., 2012; Abid et al., 2014). In this study we also adopt forward orthogonal deviations proposed by Arellano and Bover (1995) to minimize the the problem of unbalanced data.

\section{Table 1}

Description of explanatory variables in the model

\begin{tabular}{|c|c|c|c|}
\hline Related hypothesis & Variable & Notation & Calculated as \\
\hline & Return on equity & ROE & $R O E_{i t}=\frac{\text { Return }_{i t}}{\text { Equity }_{i t}}$ \\
\hline Management quality $\left(\mathrm{H}_{1}\right)$ & $\begin{array}{lr}\text { Cost-to-income ratio } \\
\text { (interest income and } \\
\text { similar sources) }\end{array}$ & INEF & $I N E F_{i t}=\frac{\text { operating } \operatorname{cost}_{i t}}{\text { Income }_{i t}}$ \\
\hline Moral hazard $\left(\mathrm{H}_{2}\right)$ & $\begin{array}{l}\text { Liquidity (equity-to-asset } \\
\text { ratio) }\end{array}$ & SOLR & 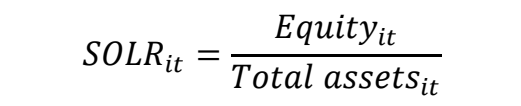 \\
\hline Diversification $\left(\mathrm{H}_{3}\right)$ & Non-interest income & NII & $N I I_{i t}=\frac{\text { non }- \text { interest } \text { income }_{i t}}{\text { total }_{\text {income }}}$ \\
\hline Ownership control $\left(\mathrm{H}_{4}\right)$ & Level of shareholding & OWN & $\begin{array}{l}\text { Ownership concentration comprises } \\
\text { dummy variables OWN1, OWN2, } \\
\text { OWN3 denoting the levels of } \\
\text { ownership of an individual and/or } \\
\text { organization of over } 10 \% \text {, over } \\
25 \% \text {, and over } 50 \% \text { of bank's } \\
\text { charter capital. }\end{array}$ \\
\hline
\end{tabular}

Data on macro variables were collated from the World Bank's dataset for the period of 2004-2014, in which we opt for 25 banks as representatives of Vietnam's commercial banks. The data sample includes three state-owned joint-stock banks (Vietinbank, Vietcombank, and BIDV) and one state-owned commercial bank (Agribank) and other joint-stock commercial banks. The data on NPLs were retrieved from Bankscope's dataset. During the survey periods, several banks including Agribank reveal negative ROE. During 2010-2011, a few joint-stock commercial banks experience losses in their 
investments, thus causing negative NII. Also, high inflation periods are also recorded with negative real interest rates.

\section{Table 2}

Descriptive statistics of variables in the model

\begin{tabular}{cccccc}
\hline Variable & No. of obs. & Mean & Std. dev. & Min & Max \\
\hline NX & 184 & 0.0136603 & 0.0099144 & 0 & 0.0505858 \\
GDP & 275 & 0.0640746 & 0.0083184 & 0.0524737 & 0.0754725 \\
LST & 275 & 2.184072 & 3.552208 & -7.332745 & 6.26011 \\
LP & 275 & 11.03956 & 5.533124 & 4.76119 & 22.67332 \\
ROE & 164 & 0.1507189 & 0.1241351 & -0.1403 & 1.1398 \\
INEF & 168 & 0.4325185 & 0.1431984 & 0 & 0.8418 \\
NII & 184 & 1.50478 & 5.514925 & -15.23375 & 55.09722 \\
SOLR & 185 & 0.0882905 & 0.0501739 & 0.0077938 & 0.4624456 \\
\hline
\end{tabular}

Note: LST and LP denote real interest rate and inflation of the economy, respectively.

\section{Results and discussion}

The estimated results using two-step GMM estimator are presented in Table 3. We adopt Windmeijer's (2005) finite sample correction to the variance/covariance matrix. For each model the results of Hansen $\mathrm{J}$ and serial correlation tests suggest the suitability of the instrument variables and no correlation among residual terms in the models.

\section{Table 3}

Regression and hypotheses testing results

\begin{tabular}{|c|c|c|c|c|c|c|}
\hline & Model 1 & Model 2 & Model $3^{a}$ & Model 4 & Model 5 & Model 6 \\
\hline L.NX & $\begin{array}{c}0.322 * * * \\
(2.62)\end{array}$ & $\begin{array}{c}0.294 * * * \\
(2.93)\end{array}$ & $\begin{array}{c}0.618 * * * \\
(4.42)\end{array}$ & $\begin{array}{c}0.380 * * * \\
(6.30)\end{array}$ & $\begin{array}{c}0.217 * * \\
(2.34)\end{array}$ & $\begin{array}{c}0.193 * * \\
(2.57)\end{array}$ \\
\hline L.ROE & & $\begin{array}{c}-0.0192 * * * \\
(-4.88)\end{array}$ & & & & \\
\hline OWN1 & & & $\begin{array}{c}0.00231 * * \\
(2.31)\end{array}$ & & & \\
\hline OWN2 & & & $\begin{array}{c}0.00665^{* * * *} \\
(4.52)\end{array}$ & & & \\
\hline OWN3 & & & $\begin{array}{c}0.00308 \\
(0.89)\end{array}$ & & & \\
\hline L.INEF & & & & 0.0142 & & \\
\hline
\end{tabular}




\begin{tabular}{|c|c|c|c|c|c|c|}
\hline & Model 1 & Model 2 & Model $3^{\mathrm{a}}$ & Model 4 & Model 5 & Model 6 \\
\hline & & & & $(0.75)$ & & \\
\hline L.SOLR & & & & & $\begin{array}{c}-0.0414 * * \\
(-2.57)\end{array}$ & \\
\hline L.NII & & & & & & $\begin{array}{c}-0.0000446 \\
(-1.48)\end{array}$ \\
\hline L.GDP & $\begin{array}{c}-0.0864 * \\
(-1.85)\end{array}$ & $\begin{array}{c}-0.126^{* *} \\
(-2.15)\end{array}$ & $\begin{array}{c}-0.0748 * \\
(-1.92)\end{array}$ & $\begin{array}{l}-0.104 \\
(-0.82)\end{array}$ & $\begin{array}{c}-0.118 * * \\
(-2.04)\end{array}$ & $\begin{array}{c}-0.157 * * \\
(-2.43)\end{array}$ \\
\hline L.LST & $\begin{array}{c}0.0529 * * \\
(2.09)\end{array}$ & $\begin{array}{c}0.0701 * * * \\
\quad(3.25)\end{array}$ & $\begin{array}{c}0.0790 * \\
(1.84)\end{array}$ & $\begin{array}{c}0.0610^{* *} \\
(2.40)\end{array}$ & $\begin{array}{c}0.0600 * * \\
(2.18)\end{array}$ & $\begin{array}{c}0.0664 * * \\
(2.12)\end{array}$ \\
\hline L.LP & $\begin{array}{c}0.0315^{* *} \\
(2.00) \\
\end{array}$ & $\begin{array}{c}0.0429 * * \\
(2.50) \\
\end{array}$ & $\begin{array}{c}0.0590 * * * \\
(3.14) \\
\end{array}$ & $\begin{array}{c}0.0456^{* *} \\
(2.46) \\
\end{array}$ & $\begin{array}{c}0.0389 * * \\
(2.30) \\
\end{array}$ & $\begin{array}{c}0.0420 * * \\
(2.15) \\
\end{array}$ \\
\hline Obs. & 146 & 110 & 168 & 140 & 142 & 143 \\
\hline Hansen & 19.73 & 12.56 & 14.58 & 20.76 & 20.27 & 20.92 \\
\hline [p_value] & 0.956 & 0.323 & 0.334 & 0.868 & 0.909 & 0.914 \\
\hline $\mathrm{AR}(1)$ & -1.844 & -2.044 & -2.088 & -2.152 & -1.877 & -2.121 \\
\hline [p_value] & 0.0652 & 0.0410 & 0.0368 & 0.0314 & 0.0605 & 0.0339 \\
\hline $\mathrm{AR}(2)$ & 0.820 & -0.777 & 1.440 & 1.653 & 0.0246 & 0.900 \\
\hline [p_value] & 0.412 & 0.437 & 0.150 & 0.0983 & 0.980 & 0.368 \\
\hline
\end{tabular}

Notes: standard errors are in parentheses; $*$, **, and *** denote significance levels of $10 \%, 5 \%$, and $1 \%$; $\mathrm{L}$ is the lag operator. The Hansen-J test suggests suitability of the models with the null hypothesis that the instruments used in the models are appropriate; $A R(j)$ with $j=1,2$ denotes serial correlation test with the null hypothesis that no correlation exists in $\mathrm{j}$ order.

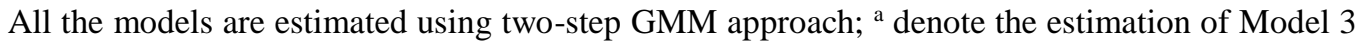
using system GMM method due to the existence of the dummy variables OWN1, OWN2, and OWN3.

Regression coefficients of lag of NPLs ( $\left.N X_{i, t-1}\right)$ are positive and significant at $1 \%$ and 5\% levels, which are consistent with the findings of Salas and Saurina (2002) for the case of Spain, Gueddoudj (2013) for Luxembourg's commercial banks, and Nkusu (2011) for developed economies. These outcomes are also quite in line with accounting principles due to the fact that NPLs of banks can be recorded in the accounting balance sheet for many years ${ }^{2}$ (Jesus \& Gabriel, 2006; Dash \& Kabra, 2010; Misra \& Dhal, 2010).

For bank internal factors the testing results are summarized in Table 4 regarding various economic theories. 


\section{Table 4}

Results of experimental tests for different economic theories

\begin{tabular}{lccc}
\hline Related hypothesis & Notation & Expected sign & Result \\
\hline Management quality & ROE & - & As expected, significant \\
Moral hazard & INEF & + & As expected, not significant \\
Diversification & SOLR & - & As expected, significant \\
Ownership control & NII & - & As expected, not significant \\
\hline
\end{tabular}

The results of testing different hypotheses in connection with banks' internal factors are reported for all the models except for the first one. We find that the internal factors existing in the models have no effects on the signs of regression coefficients of macro variables. This reveals the stability in the nexus between the macro variables and the dependent one (NPLs).

Regression coefficients of the variables adopted to test the hypothesis on the commercial banks' management quality have signs as anticipated (Berger \& DeYoung, 1997; Boudriga et al., 2009; Cotugno et al., 2010; Louzis et al., 2012). Still, the testing results suggest that only $\mathrm{ROE}_{\mathrm{it}}$ is statistically significant at $1 \%$ level, whereas $\mathrm{INEF}_{\mathrm{it}}$, which represents the degree of bank cost control, is not significant. $\mathrm{ROE}_{\mathrm{it}}$ is used to proxy for the quality of credit management of the banks; thus, its negative sign implies that poor management quality reflected in the previous term would increase NPLs subsequently. The regression coefficient of $\mathrm{INEF}_{\text {it }}$ indicates that inefficient cost control will be conducive to rising NPLs. Overall, signs of the quality management's proxies all demonstrate that management practices are still far from efficiency.

The empirical results also find moral hazard evident in the sign and significance level of SOLR $\mathrm{it}_{\mathrm{it}}$ When liquidity reduces, commercial banks with low equity ratios are likely to involve themselves in overheated credit growth to tackle liquidity related problems. Similar findings are confirmed by Salas and Saurina (2002), Gueddoudj (2013), and Abid et al. (2014).

Additionally, the hypothesis on ownership control is demonstrated by our findings which suggest that regression coefficients of the dummy variables that proxy for ownership levels of over 10\%, 25\%, and 50\% are significant at $1 \%$ and $5 \%$ levels. 
However, their signs are in contrast with earlier literature, and this is also supported by Louzis et al. (2012). Like Greek banks capitalization of the Vietnam's commercial banking system is allocated chiefly among the ones with state ownership, in which state capital accounts for a large proportion. Some state-owned banks offer loans to a few specific industries or poor households; thus, their levels of NPLs are reported to have long been higher than the average rate in the banking industry.

Nevertheless, we do not find any evidence to support the hypothesis of reduced NPLs

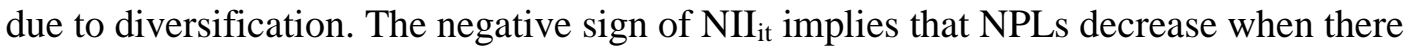
are more products as launched by banks besides such a primary one as their credit program, but this is not statistically significant.

Regression coefficients of the macro variables are significant and carry signs which are in line with extant theories and empirical studies in other countries, such as Salas and Saurina (2002), Nkusu (2011), Louzis et al. (2012), Gueddoudj (2013), and Abid et al. (2014).

\section{Conclusion and policy implications}

\subsection{Conclusion}

By employing dynamic panel data together with the GMM technique, we analyze the effects of internal factors on levels of NPLs among Vietnam's commercial banks. After controlling for the systemic impact of macro variables, we argue that the findings regarding NPLs underpin the concepts of banks' "management quality" and "moral hazard." Nevertheless, ownership control is not in line with the extant literature, and nor is any evidence gathered supporting "diversification" of banking activities.

As regards the hypothesis on "management quality", the empirical results suggest that low profitability (poor management capacity) in previous terms is one of the causes of increased NPLs in later terms. Accordingly, the bad quality of management practices is likely to trigger risky lending activities, thus resulting in rising NPLs. The issue of NPLs, in addition, is a mounting concern among many commercial banks with state ownership.

\subsection{Policy implications}

Since it is demonstrated by the research results that poor management capacity is associated with low profitability and rising NPLs, banks should take better account of 
the predictability of different profitability indicators. In case of the previous year's low level of profitability, bank managers are supposed to make risky credit decisions to cope with shareholders' pressure for increased profits. On the other hand, it is necessary for banking institutions to supervise their personnel, both managerial staff and employees, and to periodically arrange vocational training courses and examinations on which strict standards can be imposed for prompt layoffs on the grounds of low-skilled cases. Sales or customer relations staff is the very first and essential link in the whole process of bank's credit provision, from the first access to disbursement, loan supervision, and collection; enhancing capacity for efficient credit management should be thus accentuated.

To reduce the negative effect of moral hazard on banks with low equity, methods of communication need to be developed between the owner and the representative. The process of credit control and approval is to be further revised to detect any gap and be upgraded in order to ensure transparency of the information related to credit decisions. Furthermore, during bank's credit processes, there is a need to have a balance between the maximum limit approved by the representative (General Director, branch manager, transaction manager, etc.) and the possibility of bank's credit development. In fact, setting the approved limit may mitigate the moral hazard impact, but prolong the credit approval duration that affects its course of development.

State ownership is proved to have influence on commercial banks' NPLs; thus, it can be recommended that the stages of privatizing state-owned banks be accelerated, such that Vietcombank's shares are acquired by Mizuho Bank and Bank of Tokyo-Misubishi UFJ. This solution well suits the current setting and context, allowing domestic banks to enhance their management capacity due to proper control of their foreign counterparts. Problem loans, in addition, exist in the banks' balance sheet; thus, upon the merging of poorly performing banks, the problem of non-performing loans should be definitely settled.

Also, macro factors do have effects on banks' lending activities and customers' repayment capacity. Since these factors are usually out of control, commercial banks should be prepared for the changes of the macro economy to maintain their assets. During stress tests, more consideration of the macro factors not only helps with proactive responses to shocks of the economy but also enables banks to forecast loan loss 
provisions. Based on the results, sound strategies can be formulated, thus ensuring both banks' profitability and assets

\section{Notes}

1 see more at http://www.tapchitaichinh.vn/thi-truong-tai-chinh/vang---tien-te/2015-nam-ban-lethuc-hien-de-an -xu-ly-no-xau-57658.html.

${ }^{2}$ According to Circular No. 02/2013/TT-NHNN, Group 5 (possibly irrecoverable principal) includes those turned overdue for over 360 days.

\section{References}

Abid, L., Ouertani, M. N., \& Zouari-Ghorbel, S. (2014). Macroeconomic and bank-specific determinants of household's non-performing loans in Tunisia: A dynamic panel data. Procedia Economics and Finance, 13, 58-68.

Arellano, M., \& Bond, S. (1991). Some tests of specification for panel data: Monte Carlo evidence and an application to employment equations. The Review of Economic Studies, 58(2), 277-297.

Arellano, M., \& Bover, O. (1995). Another look at the instrumental variable estimation of errorcomponents models. Journal of Econometrics, 68(1), 29-51.

Bangia, A., Diebold, F. X., Kronimus, A., Schagen, C., \& Schuermann, T. (2002). Ratings migration and the business cycle, with application to credit portfolio stress testing. Journal of Banking \& Finance, 26(2), 445-474.

Barisitz, S. (2011). Nonperforming loans in CESEE-what do they comprise. Focus on European Economic Integration, Q4, 46-68.

Barisitz, S. (2013). Nonperforming loans in Western Europe-A selective comparison on national definitions. Focus on European Economic Integration, Q1/13, Vienna: OeNB. 28-47.

Berger, A. N., \& DeYoung, R. (1997). Problem loans and cost efficiency in commercial banks. Journal of Banking \& Finance, 21(6), 849-870.

Berle, A., \& Means, G. (1932). The modern corporation and private property. NY: Harcourt, Brace, $\&$ World.

Blundell, R., \& Bond, S. (1998). Initial conditions and moment restrictions in dynamic panel data models. Journal of Econometrics, 87(1), 115-143.

Boudriga, A., Boulila Taktak, N., \& Jellouli, S. (2009). Banking supervision and nonperforming loans: A cross-country analysis. Journal of Financial Economic Policy, 1(4), 286-318.

Carey, M. (2002). A guide to choosing absolute bank capital requirements. Journal of Banking \& Finance, 26(5), 929-951. 
Cotugno, M., Stefanelli, V., \& Torluccio, G. (2010). Bank intermediation models and portfolio default rates: What's the relation? Paper presented at the 23rd Australasian Finance and Banking Conference 2010 Paper. Sydney, Australia.

Dash, M. K., \& Kabra, G. (2010). The determinants of non-performing assets in Indian commercial bank: An econometric study. Middle Eastern Finance and Economics, 7(2), 94-106.

Dinh, T. T. V. (2012). Comparing non-performing loans, and classifying loans and loan loss provisions in accordance with Vietnamese and international standards (in Vietnamese). Banking Review, 19, 5-12.

Gueddoudj, S. (2013). Fluctuations economiques et dynamiques de la constitution de provisions pour créances douteuses des banques Luxembourgeoises (WP No.81). Luxembourg: Central Bank of Luxembourg.

Guyb, K. (2011). Non-performing loans. Economic Review, 37(1), 7-10.

Hu, J. L., Li, Y., \& Chiu, Y. H. (2004). Ownership and nonperforming loans: Evidence from Taiwan's banks. The Developing Economies, 42(3), 405-420.

Iannotta, G., Nocera, G., \& Sironi, A. (2007). Ownership structure, risk and performance in the European banking industry. Journal of Banking \& Finance, 31(7), 2127-2149.

Jesus, S., \& Gabriel, J. (2006). Credit cycles, credit risk, and prudential regulation. International Journal of Central Banking, 2(2), 65-98.

Judson, R. A., \& Owen, A. L. (1999). Estimating dynamic panel data models: A guide for macroeconomists. Economics Letters, 65(1), 9-15.

Karim, M. Z. A., Chan, S. G., \& Hassan, S. (2010). Bank efficiency and non-performing loans: Evidence from Malaysia and Singapore. Prague Economic Papers, 19(2), 118-132.

Louzis, D. P., Vouldis, A. T., \& Metaxas, V. L. (2012). Macroeconomic and bank-specific determinants of non-performing loans in Greece: A comparative study of mortgage, business, and consumer loan portfolios. Journal of Banking \& Finance, 36(4), 1012-1027.

Merkl, C., \& Stolz, S. (2009). Banks' regulatory buffers, liquidity networks, and monetary policy transmission. Applied Economics, 41(16), 2013-2024.

Messai, A. S., \& Jouini, F. (2013). Micro and macro determinants of non-performing loans. International Journal of Economics and Financial Issues, 3(4), 852-860.

Misra, B. M., \& Dhal, S. (2010). Pro-cyclical management of banks' non-performing loans by the Indian public sector banks. Mumbai, India: Department of Economic Analysis and Policy, Reserve Bank of India.

Nguyen, K. D. (2013). Valuation in management of non-performing loans in the current Vietnam's commercial banking system (in Vietnamese). Journal of Development and Integration, 7(17), 1421. 
Nguyen, M. T. (2012). International insights into the handling of non-performing loans in the Vietnamese commercial banking system and policy implications for Vietnam (in Vietnamese). Retrieved from http://dl.ueb.vnu.edu.vn/handle/1247/10496

Nguyen, T. N. (2013). Handling problem loans among Vietnam's commercial banks (in Vietnamese). Banking Science and Training Review, 135, 1-8.

Nkusu, M. (2011). Nonperforming loans and macrofinancial vulnerabilities in advanced economies (IMF Working Paper No. 11/161). Washington, DC: International Monetary Fund.

Perotti, R. (1996). Fiscal consolidation in Europe: Composition matters. The American Economic Review, 86(2), 105-110.

Rajan, R., \& Dhal, S. C. (2003). Non-performing loans and terms of credit of public sector banks in India: An empirical assessment. Reserve Bank of India Occasional Papers, 24(3), 81-121.

Reinhart, C. M., \& Rogoff, K. S. (2010). From financial crash to debt crisis (WP No. 15795). MA: National Bureau of Economic Research.

Rinaldi, L., \& Sanchis-Arellano, A. (2006). Household debt sustainability: What explains household non-performing loans? An empirical analysis (ECB Working Paper No. 570). Frankfurt, Germany: European Central Bank.

Salas, V., \& Saurina, J. (2002). Credit risk in two institutional regimes: Spanish commercial and savings banks. Journal of Financial Services Research, 22(3), 203-224.

Shehzad, C. T., de Haan, J., \& Scholtens, B. (2010). The impact of bank ownership concentration on impaired loans and capital adequacy. Journal of Banking \& Finance, 34(2), 399-408.

Tran, H. N., Tran, P. T., \& Nguyen, H. H. (2015). Effects of restructuring on performance of Vietnam's commercial banks (in Vietnamese). Journal of Economic Development, 26(2), 26-47.

Windmeijer, F. (2005). A finite sample correction for the variance of linear efficient two-step GMM estimators. Journal of Econometrics, 126(1), 25-51. 